\title{
The New Renewable Energy Consumption Policy of Rare Earth Metals to Build Indonesia's National Energy Security
}

\author{
Muhamad Azhar ${ }^{1,3^{*}}$,Solechan Solechan ${ }^{1}$, Retno Saraswati ${ }^{1}$, Putut Suharso $^{2}$, Suhartoyo \\ Suhartoyo $^{1}$, and Budi Ispriyarso ${ }^{1}$ \\ ${ }^{1}$ Faculty of Law, Diponegoro University, Prof. H. Soedarto SH street, Semarang 50275 Indonesia \\ ${ }^{2}$ Department of Library Science, Diponegoro University, Prof. H. Soedarto SH street, Semarang 50275 \\ Indonesia \\ ${ }^{3}$ Administrative Law Study Center, Diponegoro University, Prof. H. Soedarto SH street, Semarang \\ 50275 Indonesia
}

\begin{abstract}
This study aims to discuss the policy of using renewable energy in the form of rare metal eart as an effort to build national energy security. The research method used a legal research looking from various perspectives in social science. Law is seen as a space for the process of scientific study in order to seek truth. The use of relevant legal research wants to understand the law more thoroughly. In performing implementation analysis, using the method of Regulatory Impact Assessment (RIA) with focus on energy regulation. The results of the study show that: First, the policy of the Indonesian republic government regarding the use of new energy and renewable energy aims to prepare the carrying capacity of national energy security. This policy has not fully gone well. The policy is not supported by consistency in issuing derivative policies. Second, the use of new energy and renewable energy, especially rare earth metals as part of efforts to encourage national energy security in Indonesia is still very far from expectations. The use of rare eart metal is only around $0.7 \%$ of the use of new energy. Efforts to explore and exploit rare earth metals have not been carried out in a timely manner. Whereas the potential of rare earth metals is a strategic community and has the potential to encourage national energy security in Indonesia. Indonesia is projected to produce rare earth metals reaching $20 \%$ of the world's supply.
\end{abstract}

\section{Introduction}

The policy of using new and renewable energy (EBT) as one of the government's efforts to build national energy security in the future [1]. At present, energy use in Indonesia is still

\footnotetext{
*Corresponding author: azharundip@gmail.com
} 
dominated by fossil-based energy use, especially petroleum and coal fuels. In the near future there will be no significant new sources of energy in the next 2046, it is feared that Indonesia will experience an energy deficit. The Indonesian government must immediately make efforts to anticipate the scarcity of energy in the future [2]. One of these efforts might be done by finding new and renewable energy sources. While world energy consumption is getting longer and longer. World energy consumption continues to increase until 2017. consumption is dominated by natural gas and renewable energy. China is the highest country in the world of energy consumption.

China alone contributed over a third of that growth, with energy consumption growing by over $3 \%$ in 2017, almost three times the rate seen over the past couple of years, according to Spenser Dale[3], BP Group Chief Economist. Despite this increase, the growth of China's energy demand in 2017 was still significantly slower than its 10-year average, and its rate of decline in energy intensity was more than twice the global average. Two steps forward, one step back. The step back was coal (1.0\%, 25 Mtoe), which grew for the first time since 2013. This was largely driven by India, but it's also notable that Chinese coal consumption increased after three years of successive falls. Energy developments are: First, Primary energy consumption growth averaged $2.2 \%$ in 2017 , up from $1.2 \%$ last year and the fastest since 2013. This compares with the 10-year average of $1.7 \%$ per year. Second, By fuel, natural gas accounted for the largest increment in energy consumption, followed by renewables and then oil. And, Third, Energy consumption rose by $3.1 \%$ in China. China was the largest growth market for energy for the 17th consecutive year.

Based on this energy consumption, it can be said that the Indonesian government must find new strategies in the search for new energy sources. Indonesia is estimated to have the potential of rare earth metals in large quantities [4], both as a product itself and as a followup mineral from various mineral mines in Indonesia where potential can be found in Babel, Kalimantan, Sulawesi and Papua. rare earth metals in Babylon are metals that are in minerals following tin mining or tailings. These minerals become a by-product (slag) for processing tin ore by tin mines on the islands. Rare earth metal reserves in Babel appeared in an audit by the Supreme Audit Agency of PT Timah and PT Koba Tin, two mining companies operating in Babel.

According to 2006 data, PT Timah has 408.877 tons of monazite (containing $50-78 \%$ rare earth oxides), 57.488 tons of xenotime (containing 54-65 percent REO), and 309.882 zircons (containing yttrium and cerium). While PT Koba Tin until September 2007 had a monazite stock of 174.533 tons[5]. Unfortunately, the mineral tailings from the rest of the tin mine are only stored in a warehouse and not processed. The government has not yet determined rare earth metals as an exploration target so that the rare earth metal mineral stocks are left unattended. 


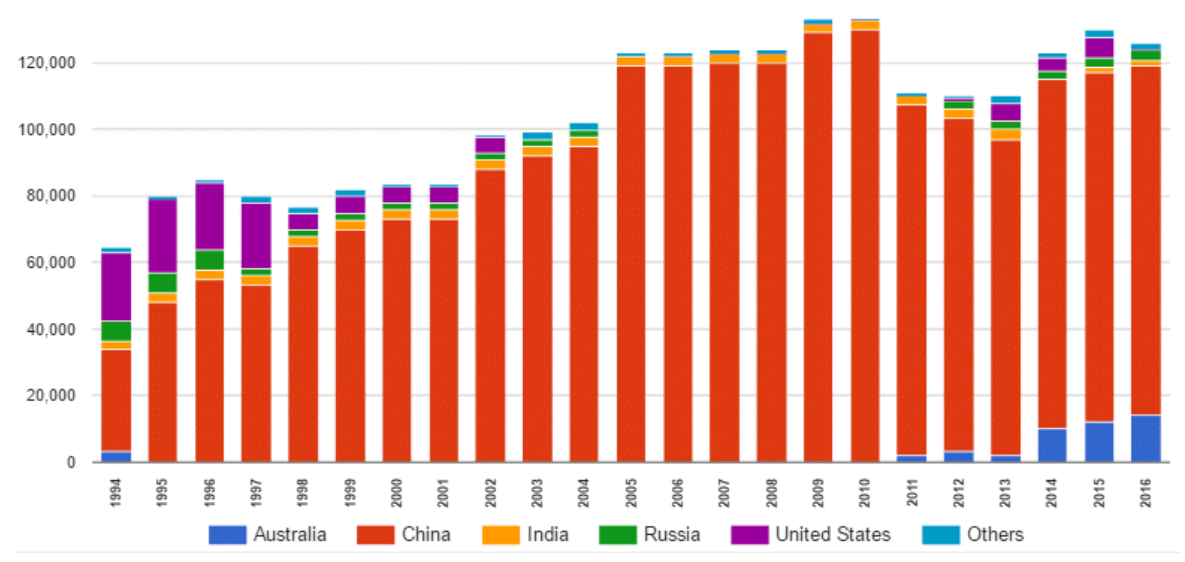

Source:https://geology.com/articles/rare-earth-elements/

Fig. 1. Rare Eart Elemet /Metal Production (Metric Tons - rare Earth equivalent)

In Indonesia, rare earth metal management is still small. The rare earth metal processing industry in Indonesia is hampered by many obstacles. One of them is a rare earth metal source with the main metal of the mine, while the secondary source is carried away by the rest of the process (tailings, filtrate) so that it is more difficult to extract. Mastery of rare earth metal technology in Indonesia has not reached commercial scale. Until now research on soil metals is rarely optimal. In Indonesia there are no specific studies that explore the potential and use of rare earth metals. Research is still done partially. Every agency on its own.

Whereas in the research of rare earth metals this requires synergy. The government seems not to have seen the potential of this rare earth metal. Further exploration activities to find out exactly how much metal reserves Indonesia has had never been done. This economic survey of rare earth metal mining has also never been carried out. Moreover, discussing rare earth metal purification technology on an industrial scale [6]. In order to develop soil metals it is rarely necessary to have partnerships and synergies between researchers, policy holders and other stakeholders. For this reason, it is necessary to prepare a road map for rare earth metal research and processing so as to encourage the development of downstream national industries that have high added value.

In connection with this description, this research will focus on the study of the Policy for the Use of Renewable Energy (Energi Baru Terbarukan-EBT) in the Form of Rare Earth Metal as an Effort to Build National Energy Resilience. The theme will focus on deepening the material related to, 1). What is the government policy related to the use of new and renewable energy in order to prepare the carrying capacity of national energy security, 2). How also the use of new and renewable energy, especially Rare Earth Metal as part of efforts to encourage national energy security in Indonesia.

Based on the background description, this research will describe the following problems: First, how is the government policy related to the use of new and renewable energy in order to equip the carrying capacity of national energy security, and Second. How also the use of new and renewable energy, especially Rare Earth Metal as part of efforts to encourage national energy security in Indonesia. 


\section{Materials and Methods}

This research is a legal research looking from various perspectives in social science. Law is seen as a space for the process of scientific study in order to seek truth. The use of relevant legal research wants to understand the law more thoroughly [7]. In performing implementation analysis, using the method of Regulatory Impact Assessment (RIA) with focus on energy regulation [8]. The need for RIA use arises from the fact that regulation generally has many impacts. It is as difficult to predict without detailed study and consultation with affected parties. The economic approach to regulatory issues also emphasizes the high risk that regulatory costs can outweigh benefits.

In this case, socio-legal research leads to a more comprehensive, intact, and not textual understanding of the law. Want to know whether the rule is effective, positive, productive, or even annoying and destructive[10]. In legal research, often using a legal approach, to obtain this qualitative truth, through the "analysis-synthesis" model. To analyze and examine data in a valid, correct structure, especially by separating it into its parts to be easily understood.

\section{Results and Discussions}

In the sub points the results of the research and this discussion will contain two discussions, namely: first, the policy of using new and renewable energy in order to prepare the carrying capacity of energy security, second, the use of rare earth metals to promote national energy security in Indonesia.

\subsection{Policy on Utilization of New and Renewable Energy in the Framework of Preparing Energy Support Capacity}

Energy has an important and strategic role to achieve social, economic and environmental goals in sustainable national development. Energy needs are expected to continue to increase as a consequence of economic growth and population growth[9]. Therefore, Energy Management is carried out as well as possible so that it can fulfill the guarantee of Energy supply for both current and future needs. Energy Management, especially the management of Energy Resources should be carried out optimally to meet the energy needs in the country. Some Primary Energy is still allocated for exports to generate foreign exchange and sources of income in the State Budget. If this is done, the energy needs in the country both as fuel and industrial raw materials will be fulfilled optimally as mandated in the provisions of Article 33 of the 1945 Constitution of the Republic of Indonesia.

If you look at Indonesia's energy future. Energy utilization is determined by the amount of new and renewable energy utilization that is reflected in government policies. The national energy mix has been designed to continue to increase the use of new and renewable energy[10]. As is known, the 2015 national energy mix consists of $39 \%$ petroleum, 22\% gas, 29\% coal, and 10\% EBT. Furthermore, in 2025 the national energy mix is planned to be $25 \%$ petroleum, $22 \%$ gas, $30 \%$ coal and $23 \%$ EBT. Then, the national energy mix in 2050 will be $20 \%$ oil, $24 \%$ gas, $25 \%$ coal, and $31 \%$ EBT (Figure. 2). 


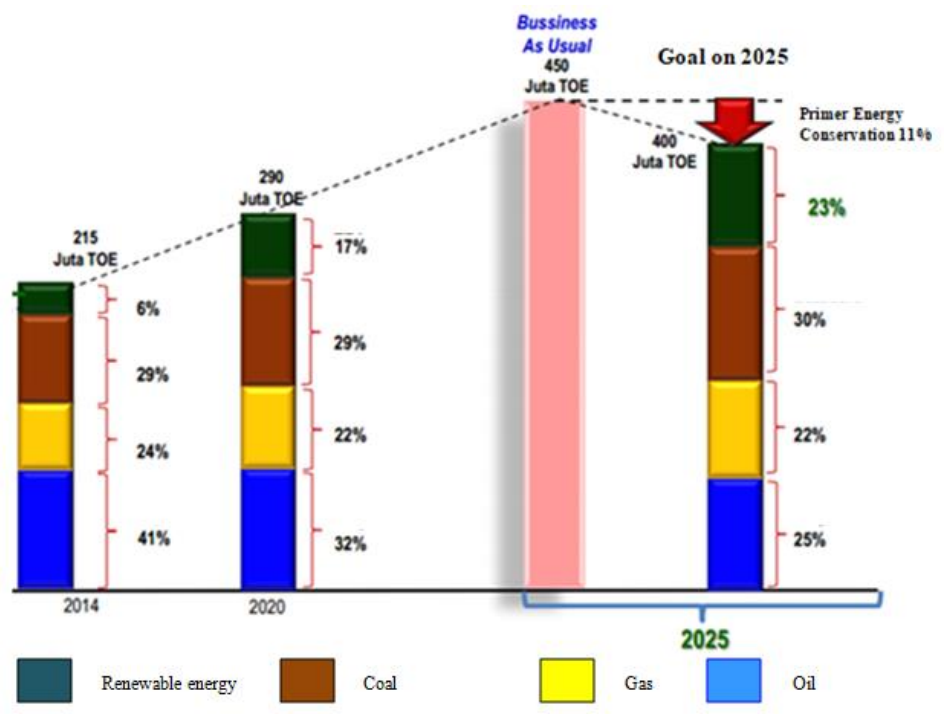

Fig. 2. National energy policy according to government regulation No. 79 of 2014[11]

There are things that are quite interesting from the prospects of energy utilization using EBT experience wear is quite significant compared to what has happened at this time, namely the use of about $6-7 \%$ of national use. As is known, fossil-based energy use will one day run out and will be replaced with renewable energy. The transition from fossilbased energy use to the use of renewable energy needs to be prepared and many challenges must be faced. Developed countries, such as France, have begun this transition through energy transition policies which were passed in the Energy Transition Act on July 22, 2015 [12]. The target to be achieved through this policy is to reduce greenhouse gas (GHG) emissions by $40 \%$ in 2030 and $75 \%$ in 2050 against the base year 1990 , increasing the efficiency of energy use by reducing the demand by $20 \%$ in 2030 and $50 \%$ in in 2050 , and diversifying energy supply by reducing the use of nuclear and fossil energy and accelerating the use of renewable energy.

Indonesia has also issued PP 79/2014 on National Energy Policy (Kebijakan Energi Nasional-KEN) which targets the use of renewable energy by $23 \%$ in 2025 and $31 \%$ in 2050 in the national energy mix. KEN has been elaborated in the National Energy General Plan which is contained in Presidential Regulation 22/2017 which is a cross-sectoral national level energy management plan. In addition, it is based on the Paris Agreement that has been ratified in Law Number 16 of 2016 concerning the Approval of the Paris Agreement to the United Nations Framework Convention on Climate Change.

So Indonesia is obliged to reduce GHG emissions by $29 \%$ on its own and by $41 \%$ with international assistance on baseline emission levels in 2030[13]. Challenges and opportunities in implementing energy transitions will continue to be faced. The use of renewable energy will still face obstacles as long as the production costs are higher than the use of fossil energy. The challenge faced today is to replace fossil-based energy with biomass which is renewable energy with cheaper production costs. Various technological innovations have been developed to reduce the cost of producing renewable energy. One important innovation is the development of biorefinery that can be used to process biomass into energy, food and other industrial materials in an integrated manner. This innovation will change the current economic paradigm based on fossils (fossil-based economy) that 
depends on coal, oil and natural gas into a bio-based economy based on the utilization of biomass.

Biomass is an abundant and carbon-neutral renewable source to produce bioenergy and biomaterials, as well as other community needs. Biomass resources can be grouped into two types of flow (flow) and type of stock. The biomass resources of the net flow type of primary productivity reaches $170 \mathrm{Gt} /$ year (about 7 times the world's energy demand) and the type of stock that is mostly in the forest reaches $1800 \mathrm{Gt}$ (around 80 times the world's energy demand)[14]. The European Union is a group of countries that have made careful plans to develop a bio-based economy since 2000. A bio-based economy is seen as having the potential to direct a country into the future that encourages sustainable development[15].Through the right policy framework, considering economic feasibility and social welfare as well as maintaining ecological sustainability, there will be greater benefits in applying bio-based economies compared to fossil-based economies. In June 2012 the European Commission established a Bio-based Industries Consortium (BIC) to plan and implement a bio-based economy in the European Union[16]. Planning includes raw materials, biorefinery, products, markets and policies. In terms of raw materials, encouraging sustainable use of biomass by increasing productivity and forming new value chains. The process for biorefinery systems is optimized to be more efficient through research and development and upscaling of demo plants.

Market development is in accordance with the products produced and supported by policies from the European Union. Indonesia is a tropical country that still has large areas of forest and plantation and agricultural land. Biomass is an important product from the management of plantation forest, and agriculture. Awareness in the management of these three sectors began to grow to utilize biomass results in a more rational way by considering economic and environmental aspects. Planning like in the European Union can be an alternative in developing Indonesia's biomass in the future. Not only biomass as alternative energy. However, new energy is also found in the form of rare earth metals or also known as rare earth elemet (REE) or rare earth (re) terms.

Rare earth metal (LTJ) or rare earth elemet (REE) or rare earth (re) are groups of 17 metal elements, which have similar chemical properties, consisting of scadium (sc) element Yotrium (Y) and 15 elements of lanthanides. The elements of the LTJ element have unique properties that are superior, so that currently LTJ is widely used in the manufacture of innovative high-tech goods such as permanent magnets, electronics, metal guides, catalyst ceramics, medical and nuclear fields, so that now the elements of LTJ are considered $21 \mathrm{st}$ century materials, some in the last decade, the need for rare earth metals in the world continues to increase. But China as a 95\% world LTJ producer limits LTJ exports to 35\% so that the LTJ price in the world soars.

Geologically, soil metals can rarely be found together with the formation of tin deposits. Mining and tin processing generally produce by-products in the form of minerals that contain rare earth elements. Tin mineralization in Southeast Asia is in the granite belt that extends south from China, continuing to Myanmar, Thailand, Peninsular Malaysia, to the Indonesian tin lane which is located extending from the Riau Islands, continuing to the south up to Bangka Belitung. In addition, tin resources in Indonesia are also found in Riau on the mainland and in Kalimantan. 


\subsection{Utilization of Rare Earth Metal to Encourage National Energy Resilience in Indonesia}

The Constitutional Court through various decisions including Decision no.3/PUUVIII/2010 concerning Testing of Law Number 7 of 2004 concerning Water Resources, provides an interpretation of the elements of state control over natural resources, which include: a) formulate policies; b) make arrangements; c) make arrangements; d) do management; and e) supervise. The Constitution of the Republic of Indonesia in 1945, hereinafter referred to as the 1945 Constitution of the Republic of Indonesia, authorizes the state to control the production branches which are important to the state and control the livelihood of many people. its obligations as stated in the Preamble of the 1945 Constitution of the Republic of Indonesia, "... protect all the people of Indonesia and all of Indonesia's bloodshed and to promote general welfare ..." and also "realize social justice for all the people of Indonesia". The state control aims to achieve the greatest prosperity of the people.

The authority to regulate the meaning, the state must regulate the allocation of management and exploitation of natural resources, including the utilization of rare earth metal to encourage national energy resilience in Indonesia[17]. Besides that, the state must be present in order to manage and manage the production branches of natural resources including rare earth metals. The existence of rare earth metals strongly supports the government's efforts as a country that produces green energy economics. In the sense that the use of natural resources is oriented to the green energy economy in various industrial and information technology sectors as shown in Figure. 3.

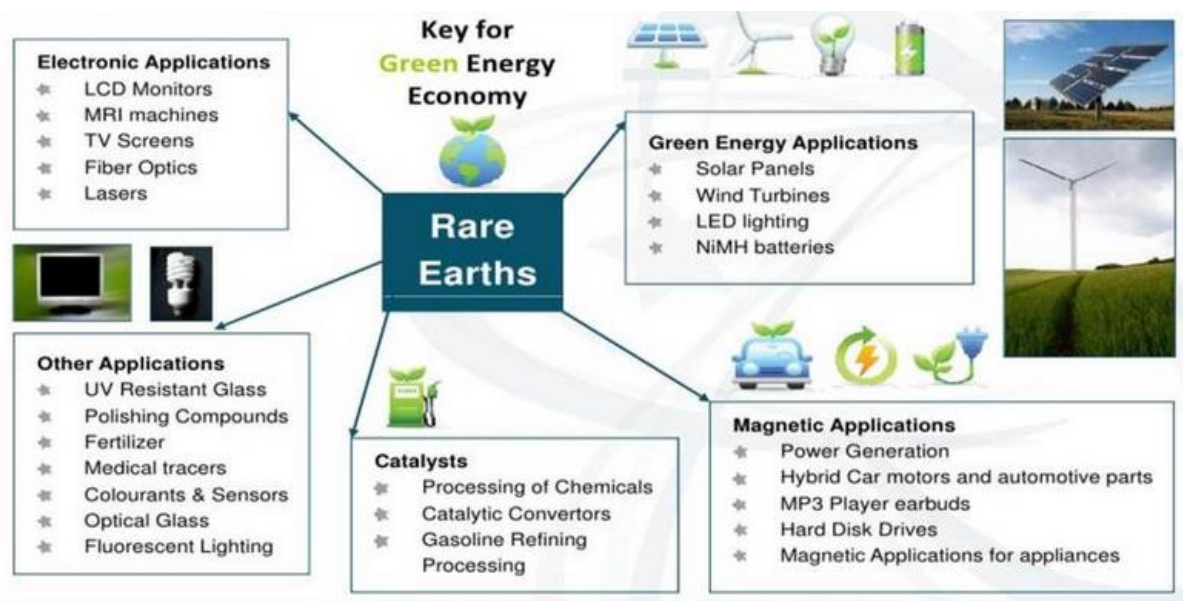

Fig. 3. Rare eart metal as a green energy economy

Later in Decision No. 001-021-022/PUU-I/2003 concerning Testing of Law Number 20 of 2002 concerning Electricity, the Court interprets that the word "controlled by the state" in Article 33 of the 1945 Constitution of the Republic of Indonesia cannot be interpreted as merely a right to regulate, because referred to "regulate" already inherent in the functions of the state without having to be specifically mentioned in the constitution. The word "controlled by the state" cannot be reduced in terms of its meaning only in relation to the authority of the state to regulate the economy. The word must be interpreted to include the meaning of state control in the broadest sense which originates and comes from the conception of the sovereignty of the Indonesian people over all sources of wealth "earth and 
water and the natural wealth contained therein", including the understanding of public by collectivity the people for the sources of wealth referred to. The people collectively constructed by the 1945 Constitution provide a mandate to the state to carry out policies (beleid) and management actions (bestuursdaad), regulations (regelendaad), management (beheersdaad) and supervision (toezichthoudensdaad) for the greatest prosperity of the people in Indonesia[18]. The description of being controlled by the state as illustrated in Figure. 4.

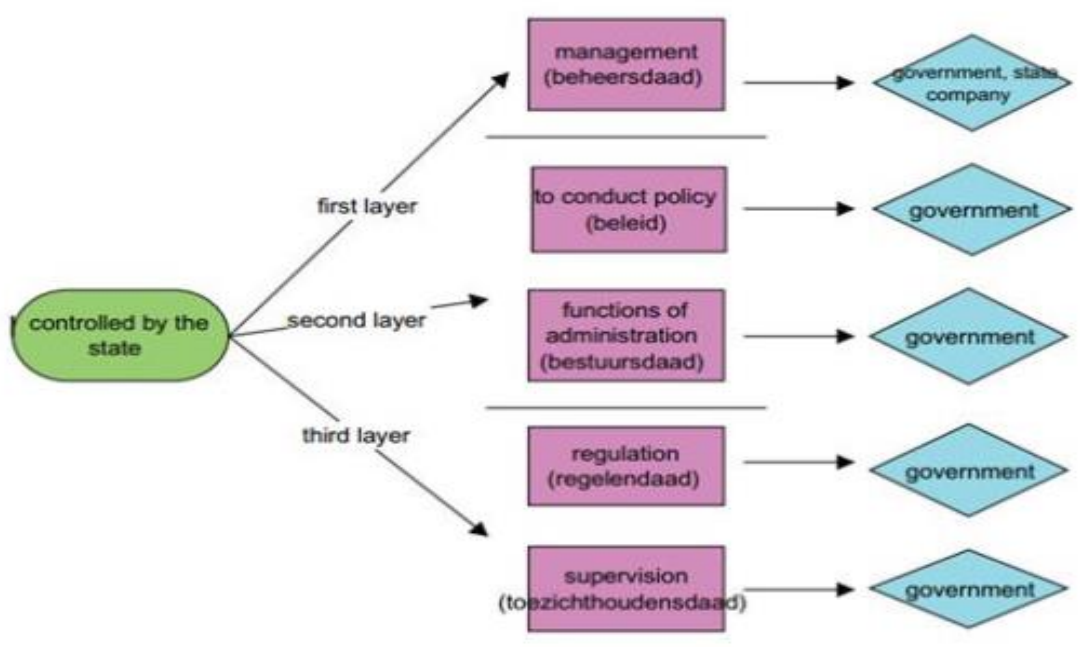

Fig. 4. Contitutional Court interpretation on Controlled by State[19]

The management function (bestuursdaad) by the state is carried out by the government with its authority to issue and revoke permit (vergunning) facilities, licenses (licentie), and concessions (concessies). State regulation functions (regelendaad) are carried out through legislative authority by the Parliament (Dewan Perwakilan Rakyat-DPR) together with the government, and regulations by the government (executive). The management function (beheersdaad) is carried out through a share-holding mechanism and/or through direct involvement in the management of the State-Owned Enterprise or State-Owned Legal Entity as an institutional instrument through which the state utilizes its control over the sources of wealth to be used for - the magnitude of people's prosperity. Likewise, the state supervision function (toezichthoudensdaad) is carried out by the state in order to supervise and control so that the implementation of control by the state over important production branches and/or which affect the livelihood of the intended people is really carried out for the greatest prosperity of all people. Included in this is the control of the state on the use of new renewable energyincluding rare earth metal to encourage national energy resilience in Indonesia.

\section{Conclusion}

Based on the overall description, it can be concluded that: First, the government policies related to the use of new and renewable energy in order to equip them with the use of new energy and renewable energy to be maximally utilized by the government, and second, utilization of new energy and renewable energy, especially energy security in Indonesia are still very far from expectations. The use of rare earth metal to encourage 
national energy are still very limited . Efforts to explore and exploit rare earth metals have not been carried out massively. Whereas the potential of rare earth metals is a strategic community and has the potential to encourage national energy security in Indonesia. Indonesia is projected to produce rare earth metals reaching $20 \%$ of the world's inventories. Encouragement to utilize the potential of new and renewable energy in the form of rare earth metal, one of which is motivated by the use of rare earth metals that are more environmentally friendly and included as one type of environmentally friendly energy or green energy economics.

\section{References}

1. S. B. Tsai et al., Energy Rev 77 (2017)

2. R. Dutu, Energy Policy 98 (2016)

3. S. Dale, Konsumsi Energi Indonesia Meningkat 5,9 Persen [Indonesian Energy Consumption Increases 5.9 Percent]. (Yogyakarta, 2017)

4. S. Mujiyanto and G. Tiess. Energy Policy 61, 5 (2013)

5. H. Asmani, Bisnis Energi 16 (2015)

6. V. Popov, A. Koptyug, I. Radulov, F. Maccari, and G. Muller, Procedia Manuf. 21 (2018)

7. S. Halliday and P. Schmidt, Conducting Law and Society Research: Reflections on Methods and Practices. (New York, Cambrige University Press, 2009)

8. A. C. M. Meuwese and S. van Voorst, Regulatory impact assessment in legal studies, (C. A. Dunlop and C. M. Radaelli, Eds. Cheltenham: Edward Elgar, 2016)

9. A. J. Bradbrook, J. Energy Nat. Resour. Law 30, 4 (2012)

10. M. Azhar and S. Suhartoyo, J. Law Reform 11,1 (2015)

11. M. Hutapea, Solusi Listrik off Grid berbasis energi terbarukan di Indonesia: kerangka regulasi dan program [Off Grid Electricity Solution based on renewable energy in Indonesia: regulatory framework and programs]. (Jakarta, Kementerian Energi Dan Sumber Daya Mineral - Direktorat Jenderal Energi Baru Terbarukan dan Konservasi Energi, 2016)

12. A. Rüdinger, The French Energy Transition Law for Green Growth: At the limits of governance by objectives, . (Paris, Institut du développement durable et des relations internationales, 2015)

13. A. Sugiyono, Pemanfaatan Bioenergi Menuju Ekonomi Berbasis Bio di Indonesia [Utilization of Bioenergy Towards a Bio-Based Economy in Indonesia]. Seminar Nasional Integrasi Proses 2017, (2017)

14. JIE, Buku Panduan Biomassa Asia: Panduan untuk Produksi dan Pemanfaatan Biomassa [The Asian Biomass Handbook: A Guide to Production and Utilization of Biomass, The Japan Institute of Energy, 2008)

15. P. Villavicencio Calzadilla and R. Mauger, J. Energy Nat. Resour. Law (2017)

16. BIC, The Bio-based Industries Visiaon: Accelerating innovation and market uptake of bio-based products. (Bio-Based Industries Consortium, 2012)

17. M. Azhar, Adminitrative Law Gov. J 1, 2 (2018)

18. M. Azhar, S. Suhartoyo, L. T. Alw, P. Suharso, and V. E. Herawati, E3S Web Conf. SCiFiMaS 47 (2018) 
19. M. E. Yuniza, M. Triatmodjo, and R. Evania. J. World Energy Law Bus 9, 2 (2016) 